\title{
Field test on the palatability of the subterranean termites to pine wood with various treatments
}

\author{
ARINANA $^{1, \boldsymbol{v}}$, AHMAD RIDHO FANNANI ${ }^{1}$, DODI NANDIKA ${ }^{1}$, NOOR FARIKHAH HANEDA ${ }^{2}$ \\ ${ }^{1}$ Department of Forest Product, Faculty of Forestry and Environment, Institut Pertanian Bogor. Jl. Ulin, Kampus IPB Darmaga, Bogor 16680, West Java, \\ Indonesia. Tel./fax. +62-251-8621677, `email: arinanaiskandaria@yahoo.co.id \\ ${ }^{2}$ Department of Silviculture, Faculty of Forestry and Environment, Institut Pertanian Bogor. Jl. Ulin, Kampus IPB Darmaga, Bogor 16680, West Java, \\ Indonesia
}

Manuscript received: 30 August 2020. Revision accepted: 25 November 2020

\begin{abstract}
Ariana, Fannani AR, Nandika D, Haneda NF. 2020. Field test on the palatability of the subterranean termites to pine wood with various treatments. Biodiversitas 21: 5763-5771. One of the keys to successfully determining the subterranean termite species' diversity in an area is using wood samples of their preference. This research aimed to evaluate the palatability of the subterranean termites to pine wood (Pinus merkusii) with boiling, steaming, hot vapor pressure, and oven treatments in the Arboretum of the Faculty of Forestry, IPB University, Bogor, West Java, Indonesia, and to analyze the species and the distribution of the subterranean termites that attacked the samples. The wood samples were $2 \mathrm{~cm} \times 2 \mathrm{~cm} \times 46 \mathrm{~cm}$ in size (ASTM D 1758-06). The steaming (100 ${ }^{\circ} \mathrm{C}$ ), boiling $\left(100^{\circ} \mathrm{C}\right)$, and hot vapor pressure $\left(1 \mathrm{bar}, 105^{\circ} \mathrm{C}\right)$ treatments were carried out for five hours, while the oven treatment $\left(103 \pm 2^{\circ} \mathrm{C}\right)$ was set up for 48 hours. Wood samples without treatment were also prepared as a control. After the treatments, all the samples were air-dried, sanded, weighed, and installed in the research location. The results showed that four subterranean termite species, i.e., Schedorhinotermes sp., Microtermes sp., Capritermes sp., and Macrotermes sp, were found attacking the wood samples. The highest attack frequency and the highest damage intensity were found in wood samples with hot vapor pressure treatment. Based on the scoring, the preeminent treatment for the wood samples was the hot vapor pressured treatment.
\end{abstract}

Keywords: Attack frequency, baiting system, damage intensity, field test, hot vapor pressure, score

\section{INTRODUCTION}

Termites are important movers of soil, depositing parts of lower strata on top of the litter layer, and termites participate in both above- and belowground parts of terrestrial ecosystems (Coleman and Wall 2015). Subterranean termites are soil macrofaunas that decompose organic materials and form topsoil structure. Their decomposition activities are more effective than the earthworms due to their gut microorganisms or the nest fungi (Kooyman and Onck 1987). Their ability to degrade lignocellulose gives termites an important place in the carbon cycle. This ability relies on their partnership with a diverse community of bacterial, archaeal and eukaryotic gut symbionts, which break down the plant fiber and ferment the products to acetate and variable amounts of methane, with hydrogen as a central intermediate. In addition, termites rely on the biosynthetic capacities of their gut microbiota as a nutritional resource (Brune 2014).

There are now over 2,600 termite species that have been described but, contrary to common belief, relatively few pose a danger to wooden structures (Kambhampati and Eggleton 2000). All termites feed on lignocellulose, which is the principal cell wall component of woody plants, and it is consumed either in the form of sound wood or in different stages of decomposition (Eggleton 2011). Determining the termite species' diversity in an area requires baits containing celluloses that the subterranean termites prefer. Wood is one of the materials containing celluloses that are easily available. Arinana et al. (2012b) reported that subterranean termites prefer pine wood (Pinus merkusii) to acacia (Acacia mangium), rubber (Hevea brasiliensis), and sengon (Falcataria moluccana). Pine wood contains chemicals that attract insects (Priawandiputra et al. 2015). Pine belongs to the family Pinaceae and is classified into class IV in terms of durability, making it susceptible to wood-destroying organisms such as wood-decay fungi, wood-staining fungi, and termites (Martawijaya 2005).

One of the keys to successfully determining the subterranean termite species' diversity in an area is using baits of their preference, indicated by the attack frequency and the damage intensity. However, using pine wood as bait requires initial treatments to increase the termites' preference. Arinana et al. (2020b) conducted laboratory research to increase $C$. curvignathus preference for pine wood by steaming, boiling, and pressure-cooking (presto) the wood for 5 hours each. The results suggested that the treatments are able to increase termites' preference for pine wood, and the highest wood weight loss $(20.32 \%)$ was found in the presto treatment. However, the research should be followed by field research to evaluate the effectiveness of the treatments on the ground. The baits should be installed in locations containing termite habitats. One of the suitable locations is the Arboretum. This research aimed to evaluate the palatability of the subterranean termites to pine wood with boiling, steaming, hot vapor pressure, and oven treatments in the Arboretum of the Faculty of Forestry and 
Environment, IPB University, Bogor, West Java, Indonesia, and to analyze the species and the distribution of the subterranean termites that attacked the samples.

These research results are expected to provide information about the termite species in the Arboretum of Faculty of Forestry and Environment, IPB University, and the preeminent treatment for the wood as bait to determine the diversity of the subterranean termites in the location.

\section{MATERIALS AND METHODS}

\section{Area study}

This research was conducted from January to July 2019 in the Arboretum of the Faculty of Forestry and Environment, IPB University, Bogor District, West Java, Indonesia. In general, the average air temperature in Bogor District is $25.2-27.0{ }^{\circ} \mathrm{C}$, the average humidity is $74-87 \%$, and the annual rainfall is $3568 \mathrm{~mm} /$ year with the number of rainy days of 177 days/year (BPS 2020). The wood samples preparation and the identification of the termites were conducted at the Laboratory of Wood Quality Improvement Technology, Department of Forest Products, Faculty of Forestry and Environment, IPB University, Bogor, West Java, Indonesia. In addition, the soil of the research location was analyzed at the Indonesian Center for Biodiversity and Biotechnology (ICBB), Bogor.

\section{Materials and Equipment}

This research used the sapwoods of the pine logs (Pinus merkusii) ( $\pm 40 \mathrm{~cm}$ in diameter) from Ciampea, Bogor, West Java, Indonesia, as the materials (Figure 1a). The logs were then sawed into boards and then into wood samples (2 $\mathrm{cm} \times 2 \mathrm{~cm} \mathrm{x} 46 \mathrm{~cm}$ in size) following the American Society for Testing and Materials (ASTM) D 1758-06 (Figure 1b). Other materials used were water for boiling and steaming processes, $70 \%$ alcohol, and oil paint (red color). Several tools used were Global Positioning System (GPS), a lux meter to measure light intensity, a fan, a moisture meter to measure the moisture content of the wood samples, bottles for termite collection, brushes, a digital camera, sandpapers, a stereo microscope, transparent plastics, and a soil driller.

\section{Procedures}

Wood samples preparation

A total of 55 wood samples were used. They were first sanded to remove the residual fibers from the cutting process before various treatments, i.e., steaming, oven, boiling, and hot vapor pressure (using an autoclave), were given. For the steaming and boiling treatments, the wood samples were steamed and boiled, respectively, for 5 hours at $100{ }^{\circ} \mathrm{C}$. They were put in an oven for the oven treatment for $2 \times 24$ hours at $100 \pm 2{ }^{\circ} \mathrm{C}$. The hot vapor pressure treatment was placed in an autoclave for 5 hours at 1 bar and $105^{\circ} \mathrm{C}$. In addition, several wood samples were given no treatments for control. After the treatments, the wood samples were air-dried using a fan for 10-14 days until their moisture content $<20 \%$. The dry wood samples were then sanded again to remove resins sticking to their surface. Each tip of the wood samples was painted and marked to distinguish them from each other. They were marked with codes indicating their respective treatment, i.e., $\mathrm{K}$ (steaming), O (oven), R (boiling), A (hot vapor pressure), and $\mathrm{C}$ (control). The wood samples were left to air dry and weighed to acquire the initial weight (W1) data before being installed in the research location.

\section{Field test and wood samples installation}

The wood samples were installed randomly and evenly in the Arboretum of the Faculty of Forestry and Environment, IPB University, spacing 6-8 meters from each other. The northernmost wood sample installation was at $6^{\circ} 33^{\prime} 26.16$ "S $106^{\circ} 43^{\prime} 46.83$ "E, the westernmost at $6^{\circ} 33^{\prime} 27.08$ "S $106^{\circ} 43^{\prime} 45.79$ "E, the southernmost at $6^{\circ} 33^{\prime} 28.08$ "S $106^{\circ} 43^{\prime} 46.83^{\prime \prime}$, and the easternmost at $6^{\circ} 33^{\prime} 26.58$ "S $106^{\circ} 43^{\prime} 47.85$ "E. See Figure 2 for the location of the wood sample installation. All the wood samples were installed vertically into the ground; the lower half-buried under the ground and the upper half (painted and marked) above the ground (Arinana et al. 2016). The wood samples were observed for three months and evaluated every month. Afterward, they were all removed, scraped clean, air-dried using a fan for 10-14 days until the moisture content $<20 \%$, and weighed (W2). The termite's attack frequency and damage intensity were then calculated.

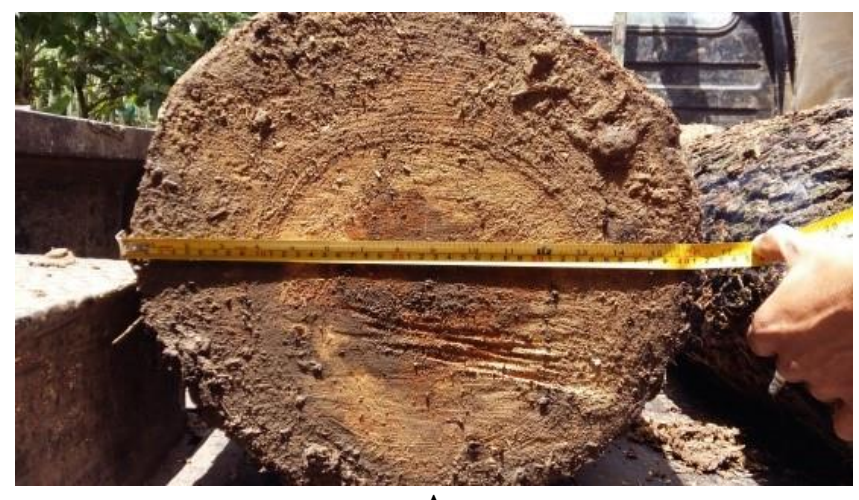

A

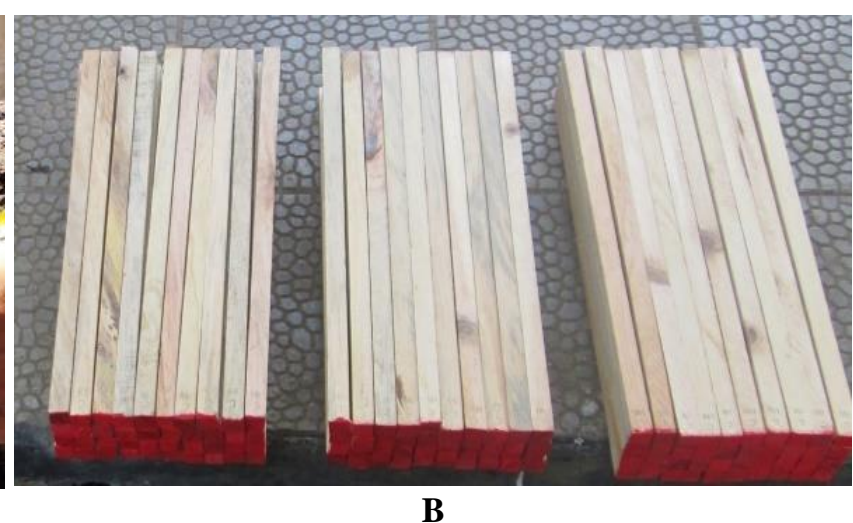

Figure 1. Pinus merkusii $\log$ (A) and wood samples (B) 


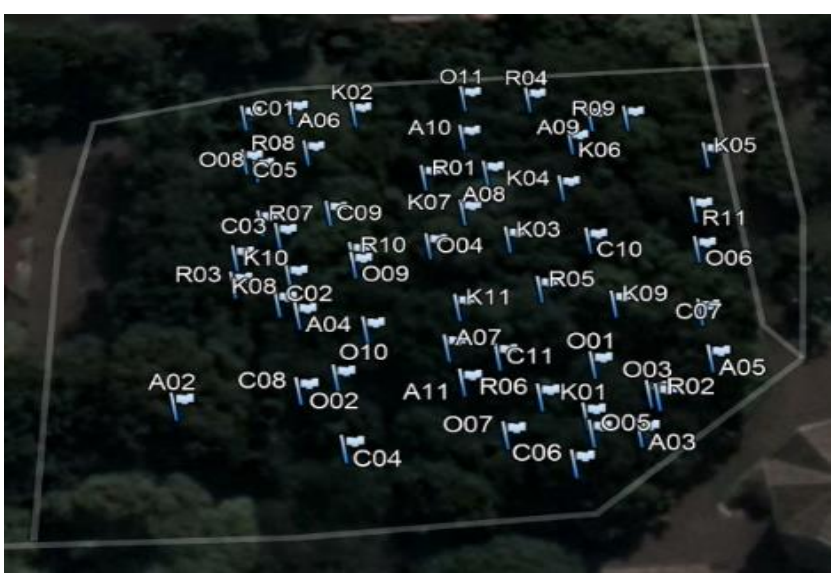

Figure 2. The location of the wood samples installation: control (C), steaming (K), oven $(\mathrm{O})$, boiling $(\mathrm{R})$, hot vapor pressure (A)

\section{Soil characteristics analysis}

To determine the soil's suitability in the research location as the habitat for the subterranean termites, a soil characteristics analysis was conducted in accordance with Arinana et al. (2016). Soil samplings were conducted at five points: four points in the cardinal directions (east, west, south, and north) and one point at the center of the field test location. The soil of $0-25 \mathrm{~cm}$ depth was taken at least $1 \mathrm{~kg}$ from each soil sampling points and put in transparent plastics. The samples were then analyzed at the ICBB Laboratory (an ISO/IEC17025 certified laboratory), Bogor, to measure soil $\mathrm{pH}, \mathrm{C}$-organic content, and soil texture.

\section{Light intensity measurement}

The light intensity was a supporting data in this research, and the measurement in the research location was conducted following Arinana et al. (2016). The sun intensity was also measured at five points: four points in the cardinal directions (east, west, south, and north) and one point at the center of the field test location. The measurements were carried out in February, March, and April 2019, three times each day, i.e., in the morning (07.00 a.m.), noon (1.00 p.m.), and afternoon (5.00 p.m.), for a total of three days each month.

\section{The identification of the termite species}

Termites attacking the wood samples were taken out and put into specimen bottles containing $70 \%$ alcohol. The identification was carried out based on literature and key identifications by Arumugam et al. (2018) and Nandika et al. (2015). The collected termites were then photographed, and each termite's entire body was observed under the microscope with 10x magnification.

\section{The attack frequency of the subterranean termites on the wood samples}

Attack frequency is the ratio between the number of the wood samples attacked by termites and the total wood samples in the Arboretum, expressed in percent (\%). Cookson and Trajstman (2002) categorized the termite's attack frequency into five classes (Table 1).

\section{The damage intensity of the wood samples}

Weight loss. Weight loss is the ratio between the decreasing weight of a sample (the initial weight minus the weight after baiting) and the sample's initial weight, expressed in percent $(\%)$. The calculation formula is as follows:

$$
W L=\frac{\left(W_{1}-W_{2}\right)}{W_{1}} \times 100
$$

Where:

WL: Weight Loss (\%)

W1: Weight of air-dried wood sample before baiting (g)

W2: Weight of air-dried wood sample after baiting (g)

Wood damage percentage. Damage percentage is the ratio between the length of the cross-sectional damage on the attacked wood sample and the wood sample's initial width or thickness, expressed in percent $(\%)$. The damage percentage is categorized into seven classes, starting from no attack to more than $70 \%$ cross-sectional damage (according to ASTM D 1758-06).

Wood sample grading system. The percentage of the cross-sectional damage determines the wood sample grading system on the wood sample due to the subterranean termite attacks (according to ASTM D 1758-06). See Table 2 for the wood sample grading system.

\section{Data analysis}

The qualitative data were presented in pictures or charts and explained descriptively. For the quantitative data, the mean values were calculated using Microsoft Excel 2016. The preeminent treatment was determined by the highest total score (1-5) of the subterranean termites' attack frequency and the damage intensity on the wood samples.

Table 1. The classification of the attack frequency of the subterranean termites (Cookson and Trajstman 2002)

\begin{tabular}{ccl}
\hline No. & Frequency $(\%)$ & Category \\
\hline 1 & $01-10$ & Very low \\
2 & $11-20$ & Low \\
3 & $12-30$ & Moderate \\
4 & $31-40$ & High \\
5 & $>40$ & Very high \\
\hline
\end{tabular}

Table 2. The grading system of the wood samples attacked by the subterranean termites (ASTM D 1758-06)

\begin{tabular}{cl}
\hline Grade no. & \multicolumn{1}{c}{ Description } \\
\hline 10 & No attack, 1 to 2 small nibbles permitted \\
9 & Nibbles to 3\% cross-section \\
8 & Penetration 3 to 10\% of cross-section \\
7 & Penetration 10 to 30\% cross-section \\
6 & Penetration 30 to 50\% cross-section \\
4 & Penetration 50 to 75\% cross-section \\
0 & Failure \\
\hline
\end{tabular}




\section{RESULTS AND DISCUSSION}

This research aimed to evaluate the palatability of the subterranean termites to pine wood with boiling, steaming, hot vapor pressure, and oven treatments in the Faculty of Forestry and Environment's Arboretum, IPB University, Bogor, West Java, Indonesia. The other purpose was to analyze the species and the distribution of the subterranean termites that attacked the samples. Before discussing the subterranean termites' palatability to pine wood, soil characteristic analysis and light intensity measurement should be carried out in the research location to obtain the necessary supporting data. Both data were required to ensure that the environment's characteristics did not deter the subterranean termites' lives in the research location and that the research's aims were eventually reached.

\section{Soil characteristics analysis}

The surface of mineral soils contains an accumulation of living biomass and dead and decomposing organic material. Soil is made up of minerals mixed with organic matter, air, water, and other organisms and covering the earth's surface. Soil is formed mainly by weathering rocks due to the physical factors in which the disintegration of rocks occurs and eventually formed into the sand, silt, and clay particles (Voroney and Heck 2015). The soil texture analysis (Table 3) suggested that the soil in the Arboretum of the Faculty of Forestry and Environment, IPB University, was clay. The sand, silt determined the soil texture and clay fractions ratio based on the soil texture triangle (Soil taxonomy USDA 2014). The study site's soil texture was the same as the research findings of Arinana (2017), located in Jakarta Province was clay. Kaschuk et al. (2006) researched the subterranean termite mounds' soil texture in five grassland locations in Santa Catarina-Brazil. The research results revealed that while the clay content in the adjacent soil and the bottom and the top of the mound was high, the center of the mound had a higher sand content. The habitat preference of the subterranean termites is related to soil textures. In general, they prefer habitats with clay soil texture and find sandy soil intolerable (Lee and Wood 1971). The soil texture is crucial in building termite tunnels above or under the ground to connect main nests with food sources. The termite tunnels are sturdier in soils with a balanced amount of sand, silt, and clay soil textures than in soils with too high clay or sand materials (Robinson 1996). Clay is important in the architecture of Macrotermitinae termite nests, and clay can increase the soil's organic matter content (Jouquet et al. 2002). Jouquet et al. (2015) stated that clay is crucial for the stability of termite mound construction.

In general, the soil $\mathrm{pH}$ of the research location was acidic, i.e., 4.5-5.7. Based on the soil $\mathrm{pH}$ classification by Balittanah (2009), the soil in the research location was strongly acidic, except the soil at the center measurement point that was found moderately acidic. According to Kaschuk et al. (2006), termites are able to survive in acidic soils, and the results of his study suggested that termite nests have soil $\mathrm{pH}$ of 4.23-5.46, while the $\mathrm{pH}$ of the soil surrounding the nests was 4.28-5.38. On the other hand, research by Mujinya et al. (2013) found that the $\mathrm{pH}$ of Macrotermes falciger mound was 3.6-8.6. Soepardi (1983) explained that organic material decomposition produces organic and inorganic acids, resulting in an acidic environment. Soil acidity is determined by the litters' organic materials and the type of vegetation in the ecosystem. The main effect of termite activity is the ability to improve soil quality (local microsite). Therefore, termites are potentially an essential source of heterogenesis in soil systems in tropical forests (Arif et al. 2019).

The C-organic content in the research location was $1.42-2.04 \%$. The C-organic content in this research was lower than the research results by Kaschuk et al. (2006). They found that the C-organic content in the soil surrounding the mounds of G. bequaerti, T. saltans, $C$. cumulans, C. fulviceps, and N. opacus in the five grassland locations in Santa Catarina-Brazil was 2.68-4.09\%, and the content was higher than at the mound base. However, the $\mathrm{C}$-organic content in this research was slightly higher than the C-organic content in the study by Arinana et al. (2020a) $(0.69-1.78 \%)$ carried out in the residential area in Bogor District, West Java. This research also found the same three species previously found in the study by Arinana et al. (2020a). Mahaney et al. (1999) stated that termites increase organic matters in the soil, and Lee and Wood (1971) stated that soils with termite activities are high in organic matters. Subi and Sheela (2020) indicated that soil organic content and $\mathrm{pH}$ affected the soil bacterial community. The surface of mineral soils contains an accumulation of living biomass and dead and decomposing organic material (Voroney and Heck 2015). Based on the soil characteristic analysis results, the soil condition in the research location did not deter the subterranean termites' lives. In addition, no soil characteristic deterred the subterranean termites' lives.

Table 2. The soil characteristics at the five measurement points in the Arboretum of the Faculty of Forestry and Environment, IPB University, Bogor, Indonesia

\begin{tabular}{|c|c|c|c|c|c|c|}
\hline \multirow{2}{*}{ Measurement points } & \multirow{2}{*}{$\mathbf{p H}$} & \multirow{2}{*}{ C-organic (\%) } & \multicolumn{3}{|c|}{ Three main fractions } & \multirow{2}{*}{ Soil texture } \\
\hline & & & Sand & Silt & Clay & \\
\hline North & 4.5 & 1.62 & 10 & 14 & 76 & Clay \\
\hline East & 4.5 & 2.04 & 10 & 15 & 75 & Clay \\
\hline South & 4.8 & 1.86 & 12 & 10 & 78 & Clay \\
\hline West & 4.5 & 1.42 & 12 & 9 & 79 & Clay \\
\hline Center & 5.7 & 1.48 & 14 & 13 & 73 & Clay \\
\hline
\end{tabular}




\section{Light intensity}

The light intensity in this research was found the highest at noon, i.e., at 13.00 GMT+7 (3889.7 lux), followed by the light intensities in the morning at 07.00 GMT+7 (359.71 lux) and in the afternoon at 17.00 GMT+7 (175.67 lux). See Figure 3 for the average light intensity. The light intensity in the research location was lower than the light intensity in South Jakarta's residential area (23,000-77,900 lux) (Arinana et al. 2016). One of the factors affecting the light intensity in the research location was plant canopy cover. Low light intensity due to dense canopy coverages causes abnormal growth in intolerant termite species.

On the other hand, the excessive light intensity will also cause abnormal growth in tolerant termite species (Herdiana et al. 2008). The amount of solar energy received daily by a location depends on the period of direct sun exposure and the land covers (forest, open land, densely-covered land, etc.). According to Axelsson and Andersson (2012), subterranean termite mounds are more abundant on shaded lands than in grasslands. The canopy cover in the Arboretum (the research location) was high, decreasing the light's intensity reaching the ground surface. Such condition was suitable for subterranean termites as they are Cryptobiotic (disliking light) (Nandika et al. 2015).

\section{The attack frequency of the subterranean termites on the wood samples}

A total of 55 wood samples were installed in the research location for three months. When the wood samples were taken out, two were missing, leaving only 53 wood samples to observe and evaluate and calculate the attack frequency and the damage intensity. The subterranean termites did not attack five out of the 53 wood samples. Therefore, the attack frequency on the overall wood samples was $88.7 \%$ (very high). Almost all of the wood samples were damaged due to the attack. Based on Cookson and Trajstman (2002) classification in Table 1, the overall attack frequency of the termites in the research location was very high, while for each treatment, the attack frequency was $16.4-20.7 \%$. The attack frequency on the wood samples with hot vapor pressure treatment was found the highest (20.7\%), followed by the attack frequency from the oven treatment (18.8\%). The attack frequency from the steaming and boiling treatments and the control were found the same $(16.4 \%$ each). These results suggested that hot vapor pressure and oven treatments are able to increase termite palatability because the attack frequencies from both were found higher than the control. See Table 4 for the attack frequency of the subterranean termites on the wood samples.

After three months of installation, the results of this research showed that the subterranean termites attacked the wood samples, with a total attack frequency of $88.7 \%$. This finding was in line with the finding in research by Arinana et al. (2020a), where the wood samples were installed in one of the residential areas in Bogor District, West Java. In that research, a total of $68.5 \%$ of pine wood samples (with the same treatments as in this research) were damaged due to subterranean termites' attack for three months. Both findings indicated that subterranean termites' attack in research locations, Bogor, West Java, was very high. Research by Haneda et al. (2017) reported that the attack frequency on pine wood samples (without any treatment) after one month of installation in Acacia crassicarpa stands in a Plantation Forest (HTI) in Riau Province, Indonesia, was $9.7 \%$. Meanwhile, the attack frequency of subterranean termites on pine wood samples without any treatments after three months of installation in a residential area in South Jakarta was 19.4\% (Arinana et al. 2016). These findings were also different from the research on damaged wood samples carried out by Arif et al. 2019 in Makassar City, South Sulawesi, Indonesia. After six months of installation, the attack frequency on the wood samples was lower than $25 \%$ (moderate).

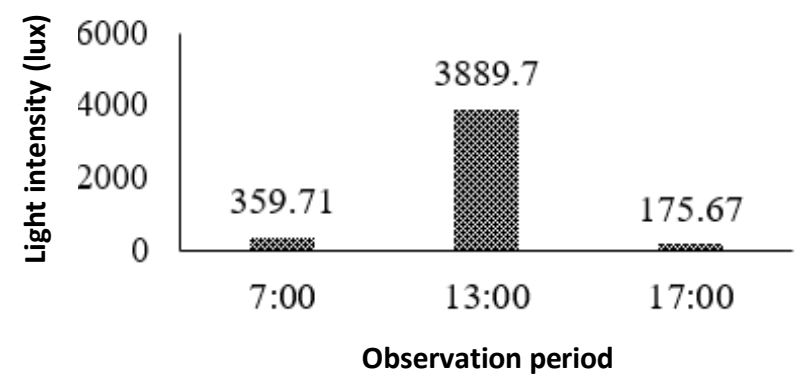

Figure 3. The light intensity in the Arboretum of the Faculty of Forestry and Environment, IPB University, Bogor, Indonesia at 07.00, 13:00, and 17.00 GMT+7

Table 3. The attack frequency of the subterranean termites on the wood samples

\begin{tabular}{lccccc}
\hline Treatment & $\begin{array}{c}\text { Number of wood } \\
\text { samples at the beginning }\end{array}$ & $\begin{array}{c}\text { Number of wood } \\
\text { samples missing }\end{array}$ & $\begin{array}{c}\text { Number of wood } \\
\text { samples attacked }\end{array}$ & $\begin{array}{c}\text { Number of wood } \\
\text { samples not attacked }\end{array}$ & $\begin{array}{c}\text { Attack } \\
\text { frequency }(\%)\end{array}$ \\
\hline Control & 11 & 1 & 9 & 1 & 1 \\
Steaming & 11 & 1 & 9 & 1 & 16.4 \\
Oven & 11 & 0 & 9 & 2 & 16.4 \\
Boiling & 11 & 0 & 11 & 0 & 16.8 \\
Hot vapor pressure & 11 & 0 & 48 & 5 & 20.7 \\
Total & 55 & 2 & & & \\
\hline
\end{tabular}




\section{The damage intensity of the wood samples Weight loss}

The wood resistance to subterranean termite attacks can be evaluated by calculating wood weight loss. After the wood sample is installed for three months, the weight loss indicates termite attacks, and it can be influenced by several factors such as termite consumption rate. This consumption rate depends on the environment, colony size, and body size of the termites. In this research, the wood samples' weight loss due to the subterranean termite attack was $21.88-36.78 \%$. The highest weight loss was found from the hot vapor pressure treatment $(36.78 \%)$, followed by the weight loss from the oven, boiling, control, and steaming treatments, i.e., $34.30 \%, 28.46 \%, 28.30 \%$, and $21.88 \%$, respectively. See Figure 5 for the weight loss data by treatments. These results suggested that hot vapor pressure, oven, and boiling treatments are able to increase termite palatability because the weight loss from the treatments was found greater than the control. In other words, subterranean termites prefer wood samples with the three treatments. Presumably, the hot vapor pressure, oven, and boiling treatments released more resin from the wood samples, making them softer and eventually increasing the termite palatability towards them. The degradation of the wood components increases along with the increases in the temperature and the duration of the treatments (Yildis et al. 2011; Huang et al. 2012; Esteves et al. 2014). In addition, the results of the research by Momohara et al. (2003) on the termite attack on Japanese cedar (Cryptomeria japonica D. Don) with hot vapor pressure treatment at various temperatures $\left(60{ }^{\circ} \mathrm{C}\right.$ to $150{ }^{\circ} \mathrm{C}$ ) and durations (6 to 72 hours) suggested that the weight loss of the Japanese cedar wood samples with $135{ }^{\circ} \mathrm{C}$ and $150{ }^{\circ} \mathrm{C}$ temperature treatments were greater than the $60{ }^{\circ} \mathrm{C}$ temperature treatment. According to Doi et al. (1999), steaming treatment can increase the termite palatability of larch wood.

\section{Wood damage percentage}

The highest wood damage percentage was found from the hot vapor pressure treatment $(85.66 \%)$, followed by the oven, control, and boiling treatments $(84.25 \%, 82.93 \%$, and $81.82 \%$, respectively), and the lowest wood damage percentage was found from the steaming treatment (69.66\%) (Figure 6). These results suggested that hot vapor pressure and oven treatments are able to increase termite palatability as the wood damage percentages from both were greater than the control. In other words, subterranean termites prefer wood samples with both treatments. Presumably, the hot vapor pressure and oven treatments released more resin from the wood samples, making them softer and eventually increasing the termite palatability towards them.

\section{Wood sample grading system}

The grade number of wood samples from all the treatments were 0 (failure), except for the steaming treatment. See Table 5 for the wood damage percentage and grade number of wood samples. The result of the grade number of the wood sample was different from the wood damage percentage. Based on the grading system, no treatment was able to increase termite palatability to the wood samples.

See Figure 7 for the various damages on the wood samples after being installed for three months in the research location. The wood samples saw a weight loss due to the subterranean termites feeding activities. Not only penetrating cross-sectionally, but the termites also ate the entire cross-section parts of the wood samples. The wood sample damages were observed visually and measured using a caliper to determine the attack's depth. The severe damage on the wood samples indicates higher termite palatability to the wood samples.

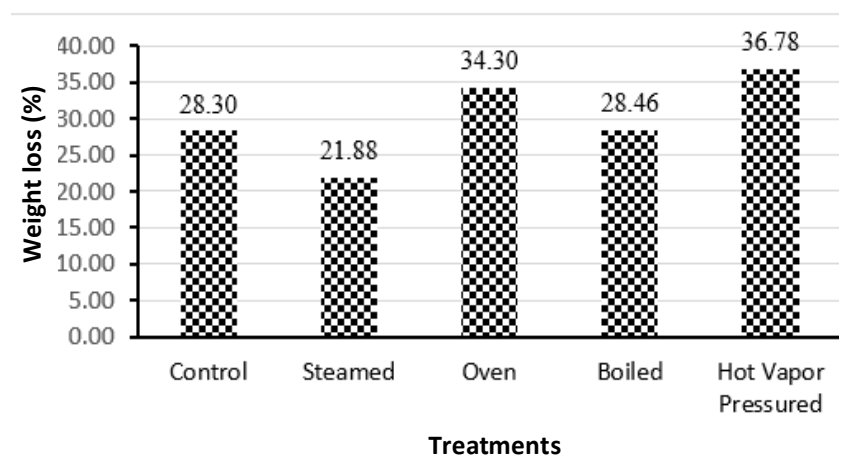

Figure 5. The weight loss of the wood samples with various treatments

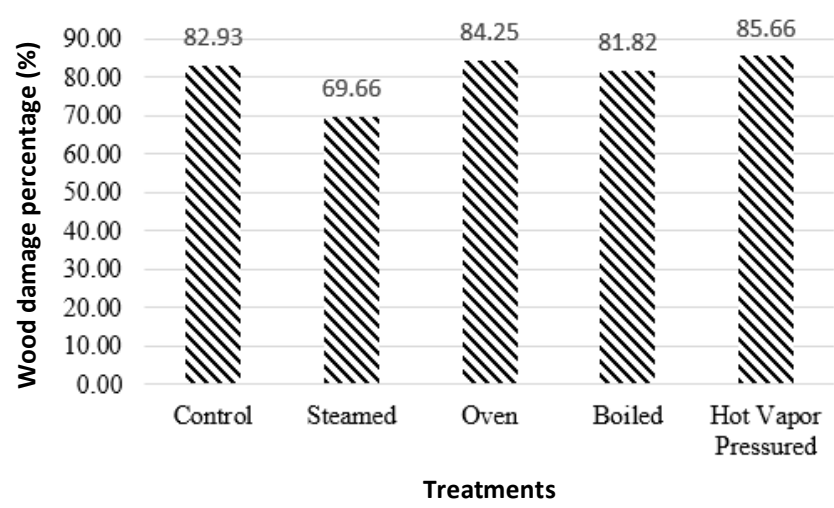

Figure 6. The wood damage percentage due to termite attack in the Arboretum of the Faculty of Forestry, IPB University, Bogor, Indonesia

Table 5. The wood damage percentage and grade number

\begin{tabular}{lcc}
\hline Treatment & $\begin{array}{c}\text { Wood damage } \\
\text { percentage }\end{array}$ & Grade number \\
\hline Control & 82.93 & 0 \\
Steaming & 69.66 & 4 \\
Oven & 84.25 & 0 \\
Boiling & 81.82 & 0 \\
Hot vapor pressure & 85.66 & 0 \\
\hline
\end{tabular}




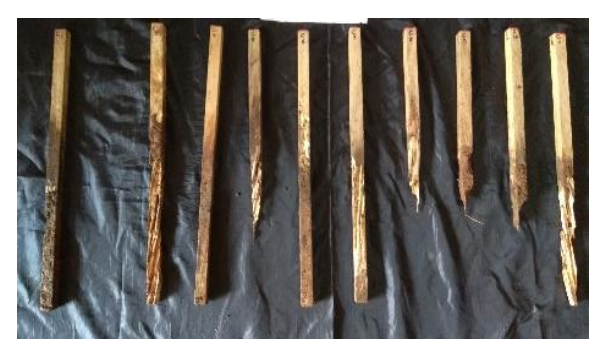

$\mathbf{A}$

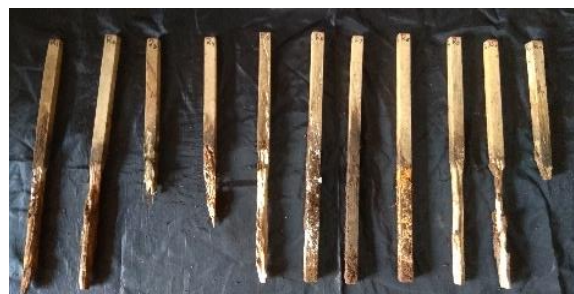

D

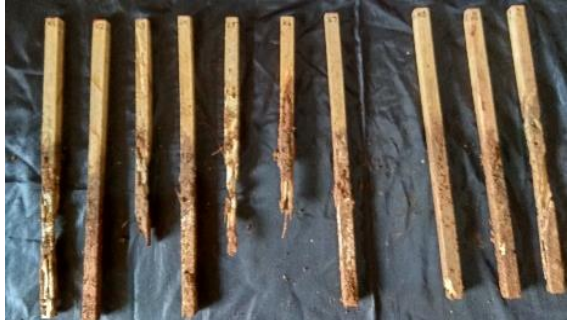

B

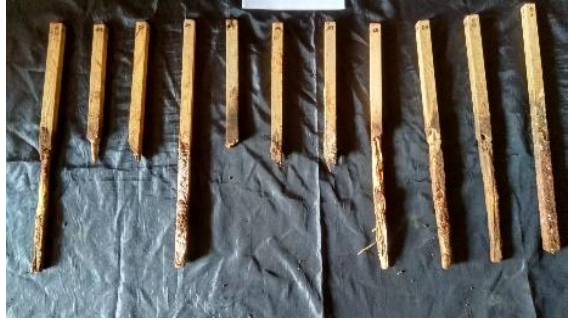

C

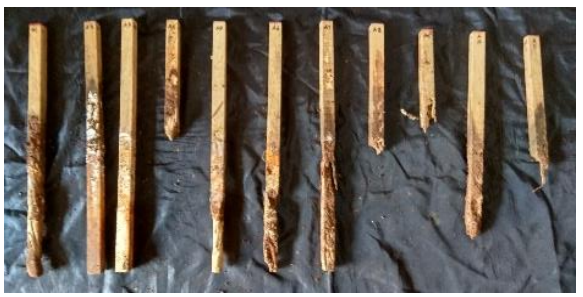

$\mathbf{E}$

Figure 7. Forms of various treated damage of wood sample after being installed for three months in the Arboretum, Faculty of Forestry and Environment, IPB University, Bogor, Indonesia: A. Control (C), B. Steaming (K), C. Oven (O), D. Boiling (R), E. Hot vapor pressure (A)

\section{Preeminent treatment}

Based on the attack frequency scores and the damage intensity (weight loss, wood damage percentage, and wood damage rate), the hot vapor pressure treatment was found preeminent. See Table 6 for the recapitulation of the preeminent treatment scores.

The highest score was found from the hot vapor pressure treatment (score 20), followed by the other treatments, i.e., oven (score 17), boiling and control (score 13 each), and steaming (score 9). Presumably, the hot vapor pressure treatment released more resin from the wood samples, making them softer. According to Arinana et al. (2020b), pine wood with presto (pressure-cooking) treatment for 5 hours was softer than with steaming and boiling treatments, presumably because the resin within the pine wood came out, decreasing the wood hardness. The hardness of the pine wood with presto treatment $(332.56$ $\left.\mathrm{kg} / \mathrm{cm}^{2}\right)$ was lower than with boiling $\left(365.77 \mathrm{~kg} / \mathrm{cm}^{2}\right)$ and steaming $\left(391.91 \mathrm{~kg} / \mathrm{cm}^{2}\right)$ treatments (Arinana et al. $2020 \mathrm{~b})$. In addition, because the treatments in the present study were not set to degrade the wood celluloses, the subterranean termites still found the wood samples favorable to consume. According to Esteves and Pereira (2009), wood chemical structures remain unchanged at temperatures up to $150{ }^{\circ} \mathrm{C}$, and the change starts at $180{ }^{\circ} \mathrm{C}$.

Table 6. The recapitulation of the preeminent treatment scores by the treatments

\begin{tabular}{lccccc}
\hline Parameter & \multicolumn{5}{c}{ Treatment score } \\
\cline { 2 - 6 } & Control & Steaming Oven & Boiling & $\begin{array}{c}\text { Hot } \\
\text { vapor } \\
\text { pressure }\end{array}$ \\
\hline Attack frequency & 3 & 3 & 4 & 3 & 5 \\
Damage intensity: & & & & & \\
$\quad$ Weight loss & 2 & 1 & 4 & 3 & 5 \\
Damage percentage & 3 & 1 & 4 & 2 & 5 \\
$\quad$ Grading system & 5 & 4 & 5 & 5 & 5 \\
Total score & 13 & 9 & 17 & 13 & 20 \\
\hline Note:
\end{tabular}

\section{The identification of the termite species}

At least four species of subterranean termites were found attacking the wood samples in the research location, i.e., Schedorhinotermes sp., Microtermes sp., Capritermes sp., and Macrotermes sp. See Figure 4 for the morphological form of the four species. Schedorhinotermes sp. was found the most dominant, and their attacks were found evenly distributed in the area. In IPB University Dramaga Campus, West Java, the species was found relatively more abundant than the other species from the family Rhinotermitidae (Mubin et al. 2019). Kuswanto et al. (2015) stated that Schedorhinotermes sp. was one of the pest termite species. Almost all the subterranean termite species found attacking pine wood samples in this research were the same species that were found in a residential area in Bogor, West Java, i.e., Schedorhinotermes sp., Microtermes sp., Macrotermes sp., and Odontotermes sp. (Arinana et al. 2020a). Capritermes sp. was not found in the residential area, and Microtermes sp. was the most dominant subterranean termite species attacking wood samples.

According to Arumugam et al. (2018), the subterranean termite Schedorhinotermes sp. is the family Rhinotermitidae and subfamily Rhinotermitinae. There are 34 living species of Schedorhinotermes in the world. This genus is widely distributed, being found in the Ethiopian, Papuan, Australian, Indo Malayan region (Tho 1992), widely distributed in the tropical regions (Nandika et al. 2015). In addition, the other three species, i.e., Microtermes sp., Macrotermes sp., and Capritermes sp., are of the family Termitidae that is also a common termite family found in the tropical regions. Research by Pribadi et al. (2011) also found Schedorhinotermes sp., Microtermes sp., and Macrotermes sp. in the eastern slopes of Mount Slamet, Central Java, Indonesia. In addition, all the species found attacking pine wood samples in this research were also found in a plantation forest in Mount Slamet, Central Java, Indonesia (Pratiknyo et al. 2018). 


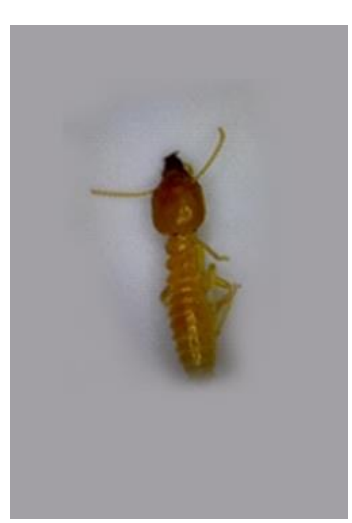

A
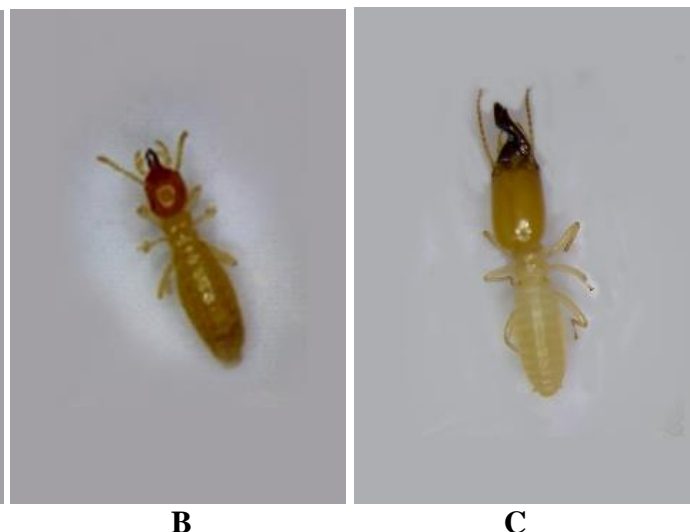

C

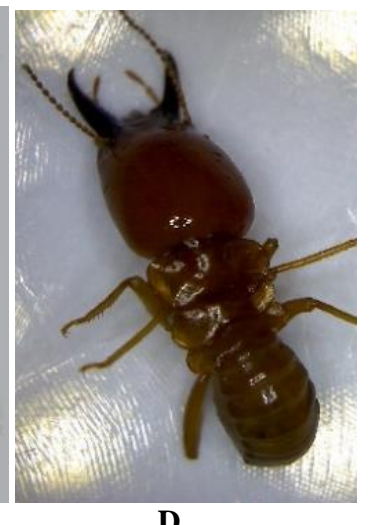

D

Figure 4. Subterranean termites that attacked the wood samples, under 10x magnification: A. Schedorhinotermes sp., B. Microtermes sp., C. Capritermes sp., D. Macrotermes sp.

Natawiria (1979) stated that Macrotermes sp. can live in hard, wet, and moist soils. According to Sulistyawati et al. (2010), subterranean termite Macrotermes gilvus Hagen was found in the Arboretum of the Faculty of Forestry and Environment, IPB University. In addition, research by Haneda et al. (2017) found five subterranean termite species in a plantation forest of Acacia crassicarpa in Bengkalis, Riau Province, i.e., Coptotermes curvignathus, C. gestroi, Schedorhinotermes javanicus, Longipeditermes longipes, and Pericapritermes mohri. On the other hand, Arinana et al. (2012a) found four subterranean termite species at an oil palm plantation in Cikasungka, Cigudeg, Bogor, i.e., M. gilvus, C. curvignathus, Nasutitermes javanicus, and Capritermes mohri. Research by Saputra et al. (2017) found 31 subterranean termite species in oil palm plantations in Malaysia dan Indonesia, including Coptotermes sp., Schedorhinotermes sp., Macrotermes sp., and Odontotermes sp. Although in these previous studies, the subterranean termite Coptotermes sp. was found, it was not found in this research. According to Kuswanto et al. (2015), the subterranean termite Coptotermes sp. is a pest of major economic importance in Asian countries (tropical and subtropical regions). This termite is a cryptic-insects that resides underground, inside trees, and remains hidden within buildings' walls.

In conclusion, the hot vapor pressure treatment at 1 bar for 5 hours using an autoclave and the oven treatment at $103 \pm 2{ }^{\circ} \mathrm{C}$ for $2 \times 24$ hours were able to increase subterranean termite palatability to pine wood on the field. The preeminent treatment to increase subterranean termites' palatability to pine wood is hot vapor pressure treatment at 1 bar for 5 hours. Subterranean termite species found in the Arboretum of the Faculty of Forestry and Environment, IPB University, were Schedorhinotermes sp., Microtermes sp., Capritermes sp., and Macrotermes sp. The most commonly found subterranean termite species in the research location was Schedorhinotermes sp., and the species was evenly distributed in the area.

\section{ACKNOWLEDGEMENTS}

The authors wish to express their appreciation to the Ministry of Research, Technology, and Higher Education of the Republic of Indonesia and IPB University, Bogor, Indonesia for supporting this research.

\section{REFERENCES}

Arif A, Putri G, Muin M. 2019. Hazard mapping of subterranean termite attack in Makassar City, South Sulawesi, Indonesia. Insects 2020, 11, 31:1-14.

Arinana, Aldina R, Nandika D, Rauf A, Harahap IS, Sumertajaya IM, Bahtiar ET. 2016. Termite diversity in urban landscape, South Jakarta, Indonesia. Insects, 720

Arinana, Haneda NF, Kahar TP. 2012a. Diversity and distribution of termite species on oil palm plantation at the PTP Nusantara VIII Bogor, West Java- Indonesia. Proceeding of the $9^{\text {th }}$ Pacific RimTermite Research Group Conference. Hanoi-Vietnam, 27-28. [Vietnam].

Arinana, Hutapea FE, Nandika D, Haneda NF. 2020a. Field Evaluation of Subterranean Termites Palatability on Treated Pine Wood in Alam Sinar Sari Residence, West Java. IOP Conference Series: Materials Science and Engineering. 935.012012

Arinana, Simamora S, Hanindita FA, Metapara J, Nandika D. 2020b. Palatability of subterranean termites Coptotermes curvignathus Holmgren treated pine wood (Pinus merkusii). Pak J Biol Sci 23 (2): 181-189.

Arinana, Tsunoda K, Hadi YS, Herliyana EN. 2012b. Termite speciessusceptible of wood for inclusion as a reference in Indonesian standardized laboratory testing. Insects. 3: 396-401.

Arinana. 2017. Pengembangan model prediksi risiko kelas bahaya serangan rayap tanah di Provinsi DKI Jakarta berdasarkan komposisi spesies serta karakteristik tanah dan iklim. [Dissertation]. Sekolah Pascasarjana IPB. Bogor. [Indonesia]

Arumugam N, Kori MSN, Rahman H. 2018. Termites identification. In Termites and Sustainable Management, Sustainability in Plant and Crop Protection. Khan MA, Ahmad W. Eds. Springer International Publishing: Basel, Switzerland.

ASTM [American Society for Testing and Materials]. 2006. ASTM D 1758-06 Standard test method of evaluating wood preservatives by field test with stakes. American Society for Testing and Materials, Pennsylvania.

Axelsson E and Andersson JA.2012. Case Study of Termite Mound Occurance in Relation to Forest Edge and Canopy Cover within the Barandabhar Forest Corridor in Nepal. Int J Biodiv Conserv 4 (15): 633-641 
Balittanah [Balai Penelitian Tanah]. 2009. Analisis kimia tanah, tanaman, air, dan pupuk. Balai Penelitian Tanah. Bogor. Indonesia [ Indonesian]

BPS [Badan Pusat Statistik Kabupaten Bogor]. 2020. Bogor District in Figure 2020. https://bogorkab.bps.go.id/publication /2020/04/27/801a42dcb801f39f4e20910d/kabupaten-bogor-dalamangka-2020.html. [Indonesian]

Brune A. 2014. Symbiotic digestion of lignocellulose in termite guts. Nat Rev Microbiol 12: 168-180

Coleman DC, Wall DH. 2015. Soil fauna: occurrence, biodiversity, and roles in ecosystem function. In: Paul EA (ed.). Soil Microbiology, Ecology, and Biochemistry, 4th ed., Elsevier, Amsterdam.

Cookson LJ, Trajstman. 2002. Termite Survey and Hazard Mapping. CSIRO Forestry and Forest Product, Clayton, USA.

Doi S, Kurimoto Y, Ohmura W, Ohara S, Aoyama M, Yoshimura T. 1999. Effects of heat treatments of wood on the feeding behaviour of two subterranean termites. Holzforsch 53 (3): 225-229.

Eggleton P. 2011. Termite Phylogenetics and Co-cladogenesis with Symbionts. In: Bignell DE, Roisin Y, Lo N (eds.). Biology of Termites: A Modern Synthesis. Springer, Dordrecht.

Esteves B, Nunes L, Domingos I, and Pereira H. 2014. Comparison between heat-treated sapwood and heartwood from Pinus pinaster. Eur J Wood Wood Prod 72: 53-60.

Esteves B, Pereira H. 2009. Pinewood modification by heat treatment: A Review. Bioresources 4 (1): 370-404.

Haneda NF, Retmadhona IY, Nandika D, Arinana. 2017. Biodiversity of subterranean termites on the Acacia crassicarpa plantation. Biodiversitas 18 (4): 1657-1662.

Herdiana N, Siahaan H, Rahman TS. 2008. Pengaruh arang kompos dan intensitas cahaya terhadap pertumbuhan bibit kayu bawang. J penelitian Hutan tanaman 5 (3): 1-7. [Indonesian]

Huang X, Kocaefe D, Kocaefe Y, Boluk Y, Pichette A. 2012. A spectrocolorimetric and chemical study on color modification of heattreated wood during artificial weathering. Appl Surf Sci 258: 53605369.

Jouquet P, Guilleux N, Chintakunta S, Mendez M, Subramanian S, Shanbhag RR. 2015. The influence of termites on soil sheeting properties varies depending on the materials on which they feed. Eur J Soil Biol 69: 74-78.

Jouquet P, Mamou L, Lepage M, Velde B. 2002. Effect of termites on clay minerals in tropical soils: fungus-growing termites as weathering agents. Eur J Soil Sci 53: 521-527.

Kambhampati S, Eggleton P. 2000. Taxonomy and Phylogeny of Termites. In: Abe T, Bignell DE, Higashi M. (eds.). Termites: Evolution, Sociality, Symbioses, Ecology. Kluwer Academic Publishers, London.

Kaschuk G, Santos JCP, Almeida JA, Sinhorati DC, Berton-Junior JF 2006. Termite activity in relation to natural grass land soil attributes. Sci Agric 63 (6): 583-588.

Kooyman CHR, Onck RFM. 1987. The interactions between termite activity, agricultural practice and soil characteristics in Kisii district, Kenya. Wageningen Agricultural University, Wageningen.

Kuswanto E, Ahmad I, Dungani R. 2015. Threat of subterranean termites attack in the Asian countries and their control: a review. Asian J Appl Sci 8 (4): 227-239.

Lee KE, Wood TG. 1971. Termite and Soil. Academic Press, London.

Mahaney WC, Zippin J, Milner MW, Sanmugadas K, Hancock RGV, Aufreiter S. 1999. Chemistry, mineralogy and microbiology of termite mound soil eaten by chimpanzees of the Mahal Mountains, Western Tanzania. J Trop Ecol 15: 565-588.

Martawijaya A. 2005. Atlas kayu indonesia jilid Il, Departemen Kehutanan Badan Penelitian dan Pengembangan Kehutanan, Bogor. Indonesia. [Indonesian]

Momohara I, Ohmura W, Kato H, Kubojima Y. 2003. Effect of high temperature Treatment on wood durability against the Brown-rot fungus, Fomitopsis palustris, and the termite, Coptotermes formosanus. In: International IUFRO Wood Drying Conference. s.l. Proceedings.1. pp. 284-287.

Mubin N, Harahap IS, Giyanto. 2019. Keanekaragaman dan kelimpahan spesies rayap (Battodea: Termitidae) di Kampus IPB Darmaga, Bogor pada berbagai tipe habitat. Prosiding Seminar Nasional PEI Cabang Bandung, Jatinangor, 25-26 Oktober 2017, 51-60. [Indonesian]

Mujinya BB, Mees F, Erens H, Dumon M, Baert G, Boeckx P, Ngongo M, Van Ranst E. 2013. Clay composition and properties in termite mounds of the Lubumbashi area, D.R. Congo. Geoderma 192: 304315.

Nandika D, Rismayadi Y, Diba F. 2015. Rayap: biologi dan pengendaliannya edisi ke-2. Universitas Muhammadiyah Surakarta Press, Sukoharjo. [Indonesian]

Natawiria DJ. 1979. Timbulnya serangan rayap Coptotermes travian Hav. dan Coptotermes curvignatus Holmgren pada tanaman kehutanan Indonesia. Lembaga Penelitian Hutan, Jakarta. [Indonesian]

Pratiknyo H, Ahmad I, Budianto BH. 2018. Diversity and abundance of termites along altitudinal gradient and slopes in Mount Slamet, Central Java, Indonesia. Biodiversitas 19 (5): 1649-1658.

Priawandiputra W, Barsulo CY, Permana AD, Nakamura K. 2015. Comparison of abundance and diversity of bees (Hymenoptera: Apoidea) collected by window traps among four types of forest on Noto Peninsula, Japan. Far Eastern Entomologist 287: 1-23.

Pribadi T, Raffiudin R, Harahap IS. 2011. Termites community as environmental bioindicators in highlands: a case study in eastern slopes of Mount Slamet, Central Java. Biodiversitas 12 (3): 235-240.

Robinson WH. 1996. Urban Entomology: Insect and Mite Pests in the Human Environment. Chapman \& Hall, New York.

Saputra A, Halim M, Jalaludin NA, Hazmi IR, Rahim F. 2017. Effects of day time sampling on the activities on termites in oil palm plantation at Malaysia-Indonesia. Serangga 22 (1): 23-32.

Soepardi G. 1983. Sifat dan ciri tanah. Departemen Ilmu Tanah. Institut Pertanian Bogor, Bogor. [Indonesian]

Soil Survey Staff. 2014. Keys to Soil Taxonomy 12th ed. United State Departement of Agriculture, Washington D.C.

Subi S, Sheela AM 2020. Review on termite mound soil characteristics and agricultural importance. J Agric Ecol Res Intl 21 (7): 1-12.

Sulistyawati I, Suhasman, dan Hadi YS. 2010. Effect of weight loss attacked by subterranean termite on mechanical properties of mangium wood. Seventh Conference of the Pacific Rim Termite Research Group, March 1-2, 2010, Singapore.

Tho YP. 1992. Termites of Peninsular Malaysia, No. 36 Malayan Forest Records. Forest Research Institute Malaysia, Kepong.

Voroney RP, Heck RJ. 2015. The soil habitat. In: Paul EA (ed.). Soil Microbiology, Ecology, and Biochemistry, 4th ed. Elsevier, Amsterdam.

Yildis S, Yildis UC, Tomak ED. 2011. The effects of natural weathering on the properties of heat-treated alder wood. Bioresources 6 (3): 2504-4502. 